\title{
PRODUCTION OF XYLAN-DEGRADING ENZYMES BY A TRICHODERMA HARZIANUM STRAIN
}

\author{
André O.Guerreiro Cacais; Fabiane Q. de Paula Silveira; Edivaldo Ximenes Ferreira Filho* \\ Laboratório de Enzimologia, Departamento de Biologia Celular, Universidade de Brasília, DF, Brasil
}

Submitted: January 19, 2001; Approved: May 28, 2001

SHORT COMMUNICATION

\begin{abstract}
Trichoderma harzianum strain 4 produced extracellular xylan-degrading enzymes, namely $\beta$-xylanase, $\beta$ xylosidase and $\alpha$-arabinofuranosidase, when grown in liquid medium cultures containing oat spelt xylan as inducer. Cellulase activity was not detected. The pattern of xylan-degrading enzymes induction was influenced by the form of xylan present in the medium. They were detected in different incubation periods. Electrophoretic separation of the proteins from liquid culture filtrates by SDS-PAGE showed a variety of bands with high and low molecular weights.
\end{abstract}

Key words: xylan, T. harzianum, xylanolytic activity

Xylans, the most abundant hemicelluloses, are comprised of D-xylopyranose units connected by $\beta-1,4$ linkages which may be linear or branched. Depending on the origin of the wood species, their degree of polymerization varies from 70 to 130 (softwood xylans) and 150 to 200 (hardwood xylans) (15). O-Acetyl-4-Omethylglucuronoxylan and arabino-4-O-metheylglucuronoxylan are the main hemicelluloses in hardwood and softwood, respectively. The latter one comprises about one-third of the total hemicelluloses (15). Xylans vary in solubility and may be isolated into water-soluble or -insoluble fractions (8). $\beta$-D-Xylanase and $\beta$-D-xylosidase are involved in the breaking down of xylan backbone to xylooligosaccharides $(1,6)$. Additional enzymes, such as acetyl xylan esterase and $\alpha$-L-arabinofuranosidase, are required to remove side-chain substituents that are attached at various points on xylan, creating more sites for subsequent enzymic hydrolysis $(2,6)$.

Selected strains from the soft-rot fungus Trichoderma have been shown to be efficient producers of xylan-degrading enzyme activity $(13,17)$. In this work, we report the production of xylandegrading enzymes obtained from liquid state cultures of Trichoderma harzianum strain 4 when grown on medium containing xylans from oat spelt as substrates.
T. harzianum strain 4 was kindly provided by I. S. Melo (National Research Center for Monitoring and Environmental Impact Assessment - Brazil). For xylan-degrading enzyme production, spore suspension from 7 days routine subculture was used to inoculate a liquid medium containing $0.5 \%$ xylan suplemented with $\mathrm{KH}_{2} \mathrm{PO}_{4}, 0.7 \% ; \mathrm{K}_{2} \mathrm{HPO}_{4}, 0.2 \% ; \mathrm{MgSO}_{4} .7 \mathrm{H}_{2} \mathrm{O}$, $0.05 \%$; $\left(\mathrm{NH}_{4}\right)_{2} \mathrm{SO}_{4}, 0.1 \%$ and yeast extract, $0.06 \%$ at $\mathrm{pH} 7.0$. The cultivation was carried out for 5 days in $1000 \mathrm{ml}$ Erlenmeyer flasks at $28^{\circ} \mathrm{C}$ and $100 \mathrm{rpm}$. Aliquots were harvested every $6 \mathrm{~h}$ during 5 days, and used to estimate xylan-degrading enzyme activities. Soluble and insoluble xylan fractions from oat spelt were prepared as described elsewhere (5). All results represent the mean of three separate experiments. Cellulase, $\beta$-xylanase, $\beta$-xylosidase and $\alpha$-arabinofuranosidase activities were determined as reported elsewhere (13). Sodium dodecyl sulphate polyacrylamide gel electrophoresis (SDS-PAGE) was performed on a $10 \%$ acrylamide gel (10). After electrophoresis, protein bands were revealed by silver staining (3). Molecular weight standards from Sigma (USA) were used as size markers.

A comparison was made of the activity of xylan-degrading enzymes from $T$. harzianum strain 4 during growth on different xylan preparations (results not shown). The carbon sources

\footnotetext{
* Corresponding author. Mailing address: Laboratório de Enzimologia, Departamento de Biologia Celular, Universidade de Brasília,. 70910-900, Brasília, DF, Brasil. Fax: (+5561) 273-4608. E-mail: eximenes@unb.br
} 
included oat spelt xylan and its soluble and insoluble fractions. The fungus did not produce cellulase activity, suggesting that the production of cellulolytic and xylanolytic enzymes is under separate regulatory control (2). The inductive effect of xylan substrates it seems to depend on their chemical composition and structure (12). The induction profile after growth on insoluble fraction of oat spelt xylan showed that the $\beta$-xylanase activity increased without a lag and was detected from the first hour to the end of cultivation period. The basal synthesis of $\beta$-xylanase suggests the production of a soluble fragment from xylan which penetrated the mycellium and effected induction of xylandegrading enzymes (9). On the other hand, the time lag for induction of $\beta$-xylanase by both oat spelt xylans and its soluble fraction was about $10 \mathrm{~h}$ and thereafter the activity increased steadily and reached the highest value at $106 \mathrm{~h}$ of cultivation. Since the degree of substitution in xylan is directly proportional to solubility (8), this result suggest that the arabinose side-chains should be a obstacle for induction of $\beta$-xylanase activity. In this case, the synergistic action of $\alpha$-arabinofuranosidase was required for the removal of arabinosyl groups from xylan (16). A low level of $\alpha$-arabinofuranosidase activity was found since the early period of growth, reaching a maximum induction at $76 \mathrm{~h}$ of cultivation.

The growth profile on all xylan preparations was accompanied by more than two peaks of xylanase activity (results not shown). The multiplicity of forms is commonly described for $\beta$-xylanases from fungi and bacteria as result of differential mRNA processing and posttranslational modifications $(4,14)$. Since all xylosidic linkages are not equivalent and equally accessible in xylan molecule, its catalytic cleavage requires the action of multiple forms of xylan-degrading enzyme systems (4). $\beta$-Xylosidase activity was only expressed at $52 \mathrm{~h}$ of cultivation in all xylancontaining media. Xylan was probably converted into small xylooligosaccharides by $\beta$-xylanases which were then further hydrolysed by $\beta$-xylosidase into xylose units (7).

SDS-PAGE analysis was performed on the crude extracts from inducing media. Fig. 1 shows the results of SDS-PAGE of the crude extract from oat spelt xylan medium. The number of protein bands suggests the effects of the inducers on the synthesis of multiple forms of xylan-degrading enzymes. The zymogram technique (11) will be necessary for identification and preliminary characterization of the multiple forms of xylanase activity. Proteins bands began to be detected at $34 \mathrm{~h}$ of cultivation period. A strong protein band with molecular weight value of about $24 \mathrm{kDa}$ was observed at the incubation range of 46-118 h. After $34 \mathrm{~h}$ of cultivation was visualized a protein band with high molecular weight size. In the above culture, a xylanase activity peak was found at cultivation period of 10-34 h. The same result was found for the inducing medium containing soluble xylan fraction. In this case, protein bands were detected after $22 \mathrm{~h}$ of cultivation. In contrast to the above results, protein bands from crude extract of growth culture containing insoluble xylan fraction as carbon source were detected in the early stage of growth. It is noteworthy that
A
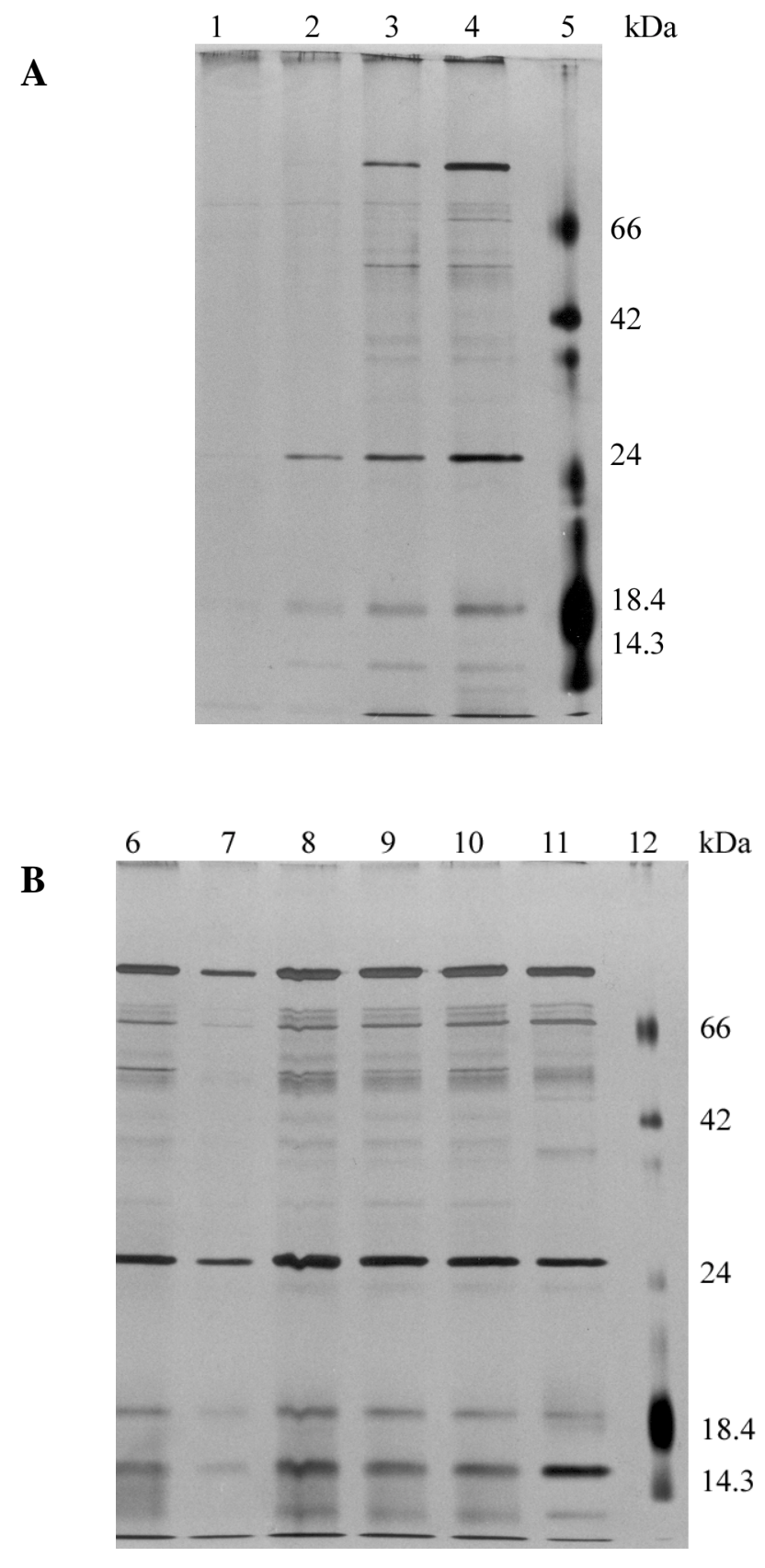

Figure 1. SDS-PAGE of the crude extract from T. harzianum strain T4 grown on oat spelt xylan. a) Lanes 1-4, 34, 46, 52 and 70 h cultivation, respectively. Lane 5 , molecular weight standards (from the top): bovine serum albumin (66 kDa); ovalbumin (42 kDa); trypsinogen (24 kDa); lactoglobulin (18.4 $\mathrm{kDa})$; lysozyme (14.3 kDa). b) Lanes 6-11, 76, 82, 94, 100, 106 and $118 \mathrm{~h}$ cultivation, respectively. Lane 12 , molecular weight standards (from the top): bovine serum albumin (66 kDa); ovalbumin (42 kDa); trypsinogen (24 kDa); lactoglobulin (18.4 $\mathrm{kDa})$; lysozyme (14.3 kDa). 
the above $24 \mathrm{kDa}$ protein band was also strongly detected at $70 \mathrm{~h}$ of cultivation. A protein band with high molecular weight size was also revealed at the same period.

In conclusion, T. harzianum strain 4 secretes a very active xylanolytic system with no cellulase activity when grown in liquid media containing different xylan forms as the carbon source. This is advantageous considering exploitation of the above fungus in biopulping and preparation of modified hemicellulose (14). Further work will be required to determine the role of these various forms of xylan-degrading activities on the mechanisms of hydrolysis of the substrate.

\section{ACKNOWLEDGEMENTS}

This work was supported by research grants PADCT III (Brazil) and FAPDF (Brazil). E.X.F.F. acknowledges receipt of a research fellowship from CNPq (Brazil).

\section{RESUMO}

\section{Produção de enzimas xilanolíticas por uma cepa de Trichoderma harzianum}

O fungo Trichoderma harzianum linhagem 4 produziu, enzimas xilanolíticas quando crescido em meios de cultura líquido contendo xilana como indutor. Atividade celulolítica não foi detectada. O tipo de xilana presente no meio de cultura influenciou a indução das enzimas xilanolíticas. As enzimas foram detectadas em diferentes períodos de incubação. SDS-PAGE de amostras de meios de cultura apresentou uma variedade de bandas protéicas com alto e baixo pesos moleculares.

Palavras-chave: xilana, T. harzianum, atividade xilanolítica

\section{REFERENCES}

1. Bajpai, P. Microbial xylanolytic enzyme system: properties and applications. Adv. Appl. Microbiol., 43:141-194, 1997.
2. Biely, P. Biochemical aspects of the production of microbial hemicellulases. In: Coughlan, M.P.; Hazlewood, G.P. (Eds). Hemicellulose and hemicellulases, Portland Press, London, 1993, p.127-143.

3. Blum, H.; Beier, H.; Gross, B. Improved silver staining of plant proteins, RNA, and DNA in polyacrylamide gels. Electrophoresis, 8:93-99, 1987.

4. Breccia, J.D.; Sineriz, F.; Baigorí, M.D.; Castro, G.R.; Hatti-Kaul, R. Purification and characterization of a thermostable xylanase from Bacillus amyloliquefaciens. Enzyme Microb. Technol., 22:42-49, 1998.

5. Filho, E.X.F.; Puls, J.; Coughlan, M.P. Biochemical characteristics of two endo-b-1,4-xylanases produced by Penicillium capsulatum. J. Ind. Microbiol., 11:171-180, 1993.

6. Filho, E.X.F. The xylan-degrading enzyme suystem. Brazilian J. Med. Biol. Res., 27:1093-1109, 1994

7. Ghosh, M.; Das, A.; Mishra, A.K.; Nanda, G. Aspergillus sydowii MG 49 is a strong producer of thermostable xylanolytic enzymes. Enzyme Microb. Technol., 15:703-709, 1993.

8. He, L.; Bickerstaff, G.F.; Paterson, A.; Buswell, J.A. Evaluation of catalytic activity and synergism between two xylanase isoenzymes in enzymic hydrolysis of two separate xylans in different states of solubility. Enzyme Microb. Technol., 16:696-702, 1994.

9. Kyu, K.L.; Ratanakhanokchai, K.; Uttapap, D.; Tanticharoen, M. Induction of xylanase in Bacillus circulans $\mathrm{B}_{6}$. Biores. Technol., 48:163167,1994

10. Laemmli, U.K. Cleavage of structural proteins during the assembly of the head of bacteriophage T4. Nature, 227:680-685, 1970.

11. Lee, Y-E.; Lowe, S.E.; Zeikus, J.G. Regulation and characterization of xylanolytic enzymes of Thermoanaerobacterium saccharolyticum B6A-RI. Appl. Environ. Microbiol., 59:763-771, 1993.

12. Saraswat, V.; Bisaria, V. Biosynthesis of xylanolytic and xylandebranching enzymes in Melanocarpus albomyces IIS 68. J. Ferment. Bioeng., 83:352-357, 1997.

13. Silveira, F.Q.P.; Melo, I.S.; Filho, E.X.F. Carbohydrate -hydrolysing enzyme activity production by solid-state cultures of Trichoderma harzianum strains. Rev. Microbiol., 28:1-5, 1997.

14. Tuohy, M.G.; Coughlan, M.P. Production of thermostable xylandegrading enzymes by Talaromyces emersonii. Biores. Technol. 39:131-137, 1992.

15. Viikari, L.; Kantelinen, A.; Sundquist, J.; Linko, M. Xylanases in bleaching: From an idea to the industry. FEMS Microbiol. Rev., 13:335350,1994

16. Ximenes, F.A.; Sousa, M.V.; Puls, J.; Silva-Jr., F.G., Filho, E.X.F. Purification and characterization of a low-molecular weight xylanase produced by Acrophialophora nainiana. Curr. Microbiol., 38:18-21, 1999.

17. Wong, K.Y.; Saddler, J.N. Trichoderma xylanases, their properties and applications. In: Visser, J.V.; Beldman, G., Kusters-Van-Someren, M.A.; Voragen, A.G.J. Xylan and xylanases, Elsevier Science Publishers, Amsterdam, 1992, p.171-186. 